\title{
Cultural role of sea turtles on Rapa Nui (Easter Island): Spatial and temporal contrast in the Pacific island region
}

\section{Rocío Álvarez-Varas}

Departamento de Ciencias Ecológicas, Facultad de Ciencias, Universidad de Chile, Chile Departamento de Ecosistemas y Medio Ambiente, Facultad de Agronomía e Ingeniería Forestal, Pontificia Universidad Católica de Chile, Chile

Millennium Nucleus Center of Ecology and Sustainable Management of Oceanic Islands, Coquimbo, Chile

Qarapara Tortugas Marinas Chile NGO, Chile

rocioalvarez@ug.uchile.cl (corresponding author)

\section{Héctor Barrios-Garrido}

TropWATER, Centre for Tropical Water \& Aquatic Ecosystem Research. James Cook University, Australia

Laboratorio de Ecología General, Centro de Modelado Científico (CMC), Universidad del Zulia, Venezuela

hector.barriosgarrido@my.jcu.edu.au

\section{lohandy Skamiotis-Gómez}

Qarapara Tortugas Marinas Chile NGO, Chile

Facultad de Ciencias del Mar y Recursos Naturales, Universidad de Valparaíso, Chile iohandysk@gmail.com

\section{Robert Petitpas}

Centro de Estudios Interculturales e Indígenas - CIIR, Pontificia Universidad Católica de Chile, Chile

Laboratorio Fauna Australis, Pontificia Universidad Católica de Chile, Chile rcpetitp@uc.cl

\footnotetext{
Abstract: Sea turtles are deeply rooted in Pacific cultures. Rapa Nui (Easter Island, Chile) has a complex societal and ecological history and marine resources have always been exploited; nevertheless, little is known about relationships between these resources and Rapanui islanders. This study aims to explore the historical and contemporary role of sea turtles on Rapa Nui, contrasting it with information from other Pacific region societies. We triangulated information through a literature review, semi-structured interviews, and participant observations. Our results show a strong cultural connection between Rapa Nui and other Pacific islands, with turtles represented in their art, culture, mythology, symbolism, popular traditions, and ritual and spiritual life. Use of these animals on Rapa Nui has varied historically, and nowadays turtle consumption is widely rejected among Rapanui community members. Currently, sea turtles have a crucial role in tourism, constituting an opportunity for local development, further knowledge, and conservation of natural heritage.
} 
Rocío Álvarez-Varas et al.

Keywords: conservation, Easter Island, heritage, Pacific islands, Rapa Nui, sea turtles

https://doi.org/10.24043/isj.111 • Received August 2019, accepted September 2019

(C) 2020 - Institute of Island Studies, University of Prince Edward Island, Canada.

\section{Introduction}

Sea turtles have played a significant role in traditional management systems on Pacific islands (Kinan \& Danzell, 2005), representing an important subsistence and cultural value for many Indigenous societies throughout the region (Luna, 2003; Wilmé, Waeber, \& Ganzhorn, 2016). Traditionally, they are known to be part of mythology, religious ceremonies and perpetuated community relationships and identities through the exchange of meat and by-products (Kinan \& Danzell, 2005; Luna, 2003, 2013). Their value in ancient and current societies show a panPacific distribution-Polynesia, Micronesia, and Melanesia-that encompass a wealth of linguistic groups and every conceivable type of social structure (Luna, 2013). Indeed, Wilmé et al. (2016) hypothesized that the early Austronesians used the migration routes of sea turtles towards their nesting grounds to locate islands in the Pacific and Indian oceans.

Although sea turtles have long been highly valued throughout the region, there has been a variability in the rules and social practices regarding their capture and consumption (Wilmé et al, 2016). Allen (2007), examining ethnographic accounts, mentions two broad patterns: some islands had strictly enforced and highly formalized sociopolitical and religious control over the use of these animals, whereas other islands exhibited much less stringent control. In contrast with the consumption of meat and by-products, the use of turtle bone and shell was less regulated. Turtle carapaces and plastrons were utilized to make many utilitarian objects (Allen, 2007). Carapace scutes were used in the manufacture of various fishhooks and net gauges (Allen, 2007), and turtle shell coins may have been used for barter in the region (McCoy, 1997).

Sea turtle use was traditionally controlled by direct management strategies and indirect social controls (Allen, 2007; Wilmé et al, 2016). However, the stronger protection afforded to turtles was probably indirect, stemming from their sacred status and numerous restrictions associated with the tapu (Proto-Polynesian language) system or traditional 'laws'. These systems provided a buffer on the number of turtles harvested, where only certain members of the community were allowed to eat turtles (Foale, Cohen, Januchowski-Hartley, Wenger, \& Macintyre, 2011). Turtles were collected for specific circumstances, and some hunts were undertaken ceremonially (Kinan \& Danzell, 2005). Tapu rituals were involved in turtle net manufacture, capture, preparation, and eating (Luna, 2003, 2013).

Nowadays, these animals continue to be a significant resource for multiple ancient cultures worldwide (e.g., Barrios-Garrido et al, 2018; Fretey, Hoinsoude, \& Soumah, 2007), including Polynesian nations (Luna, 2013, 2013). Indeed, in some islands the use of sea turtles occurs as part of their cultural rites, and provide food and also prestige and status among 
villagers (Foale et al., 2011). Furthermore, to prevent over-harvesting, multiple islands continue using taboo regimes over these animals.

Rapa Nui (in English, 'Easter Island') represents a foraging habitat for five threatened sea turtle species (Alvarez-Varas et al, 2015). It is one of the most isolated inhabited Pacific islands, famous for its megalithic statues (Moai), complex pre-European society, and its subsequent ecological and societal collapse (Friedlander et al, 2013; Hunt \& Lipo, 2009). Rapa Nui has been considered one of the most fragile environments in the Pacific by some authors (Rolett \& Diamond, 2004). Its terrestrial and marine flora and fauna are characterized as having low species diversity and high endemism (Hunt \& Lipo, 2012; Randall \& Cea, 2011), which is explained by the island's isolation, small size, relatively young geological age, low diversity of habitats, intermediate latitude, and its location to the east of Oceania (Fosberg, 1960; Friedlander et al, 2013; Randall \& Cea, 2011). The archaeological and sociological aspects of the island have been extensively studied. However, the relationship between Rapanui people and marine resources has received less attention (Wilmé et al, 2016), despite the fact that these resources have been exploited since the arrival of the first immigrants to the island (Ayres, 1979; Aburto, Gaymer, Haoa, \& González, 2015; Castilla, Yáñez, Silva, \& Fernández, 2014). Understanding the socioeconomic values, traditions, and cultural interaction among natural resources and human societies is critical to improve decisionmaking processes, especially in isolated territories (Barrios-Garrido et al, 2018).

In this context, the aim of this study is to explore the historical and contemporary role of sea turtles in Rapanui culture and contrast it with information from other Pacific region societies. Hence, our questions: i) What is the traditional cultural role of sea turtles on Rapa Nui? ii) Is this role present today? iii) Are there variations in the role of sea turtles between Rapa Nui and other islands of the Pacific region? iv) What is the current interaction between turtles and Rapanui people? All these questions were addressed through a cross-cultural ethnographic research approach.

\section{Study area}

Rapa Nui $\left(27.0724^{\circ} \mathrm{S} ; 109.2157^{\circ} \mathrm{W}\right)$ is a small island $(163 \mathrm{~km} 2)$ in the South Pacific Ocean that forms part of Chilean territory and corresponds to the easternmost corner of the Polynesian triangle (Figure 1; Aburto et al, 2015). It is located about 3,500 km west of mainland Chile and 2,800 km away from the Pitcairn Islands, the nearest populated site in the Pacific Ocean (Figueroa \& Rotarou 2016; Wilmé et al, 2016).

Although the date of initial human settlement on the island is unclear, it is proposed to be between the $8^{\text {th }}$ and $12^{\text {th }}$ century AD (Hunt \& Lipo, 2006). For generations, the Rapanui population faced deforestation, slave raids, epidemics, and colonialism (Fischer, 2005; Flenley \& King, 1984; Young, 2012). In the 1860s and 1870s, Frenchmen arrived as missionary priests and lay commercial exploiters, and domestic animals (sheep, cows, horses, pigs, donkeys, dogs, and cats) were introduced to the island (McCall, 1997). In 1888, Rapa Nui came under Chilean administration. The new Chilean order was characterized by autocratic rules, violence, prohibition of Rapanui symbols, and loss of animals and land. In this period, law and order policies, consumption goods, and cash money were introduced to the Rapanui society. Furthermore, through the church came an ideological order to the island (McCall, 1997). At the beginning of the $20^{\text {th }}$ century, during the period of the Easter Island Exploitation 
Company, and during the subsequent administration by the Chilean Navy, which began in 1952, the Rapanui population was confined to living in a fenced sector, which currently corresponds to Hanga Roa (Consejo Nacional de la Cultura y las Artes, 2012). Later, in 1968, the completion of an airstrip brought an influx of immigrants, tourists, and a greater supply of new food (Aburto et al, 2015).

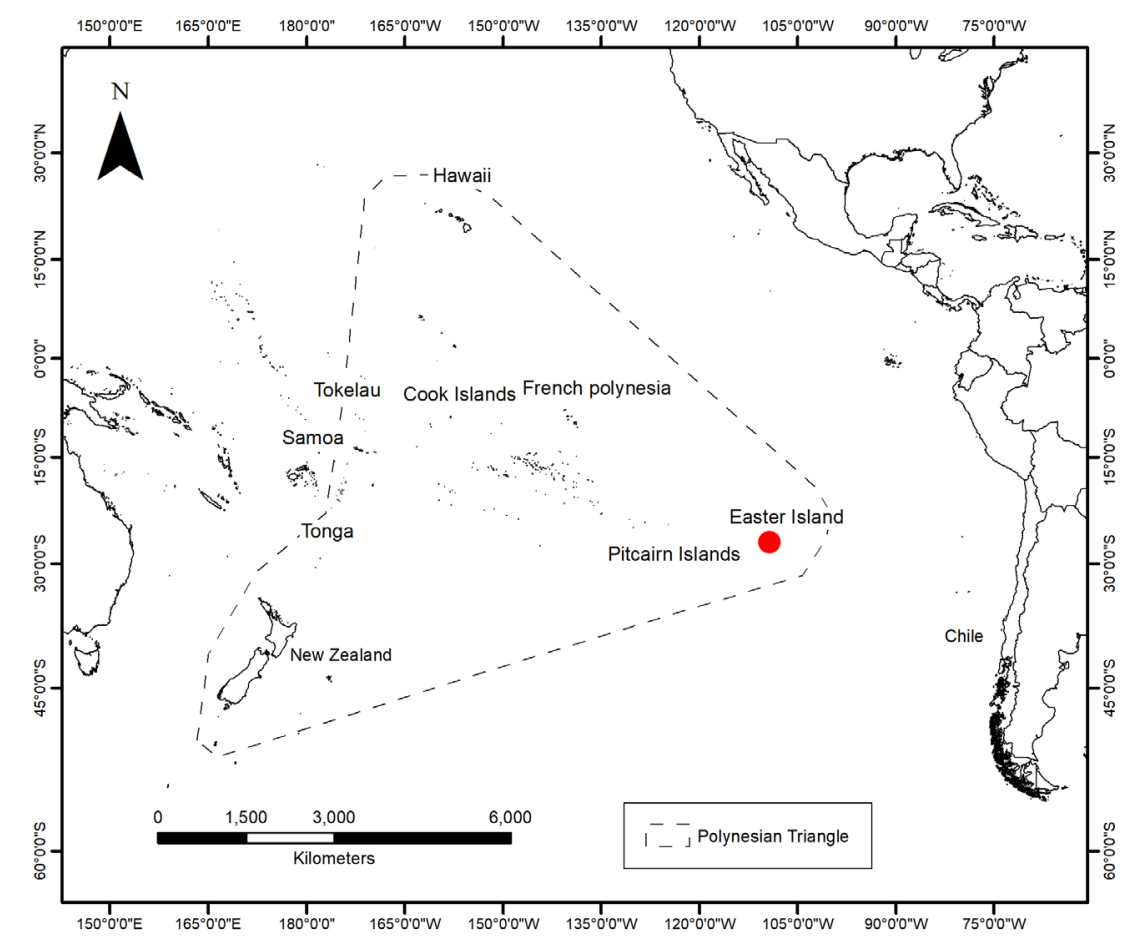

Figure 1. Polynesian triangle showing the location of Rapa Nui (Easter Island) in the south Pacific Ocean.

Today, Rapa Nui is inhabited by 7,750 people and about $45 \%$ of its residents are Rapanui people (INE, 2017; in English, 'National Statistics Institute of Chile'). Over the past decade, the tourism industry on the island has experienced marked growth, with tourists reaching almost 70,000 people annually (Figueroa \& Rotarou, 2016; Zylich et al, 2014). Tourism is indeed the main economic sector and has led to the development of infrastructure and health and education services, and it has resulted in an overall improvement in the quality of life of the population (Figueroa \& Rotarou, 2016). A recent study based on Rapa Nui residents' perceptions showed that tourism is the main future driver of the island's economy (Figueroa \& Rotarou, 2016).

\section{Methods}

Due to the unique sociocultural characteristics of Rapanui culture, our study included a crosscultural assessment with an ethnographic research approach (Cohen \& Steenbergen, 2015).

\section{Triangulation}

We used a combination of ethnographic methods. This included literature review, semistructured interviews (27 interviewees), and participant observation (Barrios-Garrido et al, 
2017; Diedrich \& García-Buades, 2009). Fieldwork on Rapa Nui was conducted in July 2011. Details on triangulation are shown in Table 1.

The literature review on Rapa Nui included historical reports exclusively available in the Universidad de Valparaíso Library (Valparaíso, Chile) and the 'William Mulloy' Library on Rapa Nui (July 2011) (Table 1). We also accessed digital databases (Google Scholar, ISI Web of Knowledge, Scopus, CIA World Fact Book, and International Work Group for Indigenous Affairs - IWGIA, 2012) in search of literature regarding sea turtles on Rapa Nui and other Pacific societies (Table 1). We used the following key words: 'sea [marine] turtles', 'honu', 'Easter Island', 'Rapa Nui', 'Pacific [Region]', 'traditional use', 'ecocide', 'consumption', 'fishing', 'Indigenous people', 'people', and 'tapu [taboo]'. Data regarding Rapa Nui was included in the results section, while information on other Pacific islands was integrated into the discussion section.

Table 1. Details of triangulation, including data on literature review, participant observation, and semi-structured interviews.

\begin{tabular}{|c|c|c|c|}
\hline Timeline & Method & Personnel involved & Places evaluated \\
\hline & $\begin{array}{l}\text { Literature review } \\
\text { (Valparaíso) }\end{array}$ & $\begin{array}{l}\text { Biologist and Master in } \\
\text { Wildlife Management and } \\
\text { Conservation (RAV, KSG) }\end{array}$ & $\begin{array}{l}\text { Universidad de Valparaiso } \\
\text { Library, Valparaiso, Chile }\end{array}$ \\
\hline 4-8 July 2011 & $\begin{array}{l}\text { Literature review } \\
\text { (Rapa Nui) }\end{array}$ & $\begin{array}{l}\text { Biologist and Master in } \\
\text { Wildlife } \\
\text { Management and } \\
\text { Conservation (RAV, KSG) }\end{array}$ & $\begin{array}{l}\text { William Mulloy Library, } \\
\text { Hanga Roa, Rapa Nui, } \\
\text { Chile }\end{array}$ \\
\hline $\begin{array}{l}11-22 \text { July } \\
2011\end{array}$ & $\begin{array}{l}\text { Participant } \\
\text { observation (Rapa } \\
\text { Nui) }\end{array}$ & $\begin{array}{l}\text { Trained biologist and Master } \\
\text { in Wildlife } \\
\text { Management and } \\
\text { Conservation (RAV, KSG) }\end{array}$ & $\begin{array}{l}\text { Hanga Roa-Hanga Piko, } \\
\text { Rapa Nui, Chile }\end{array}$ \\
\hline \multirow[t]{2}{*}{$\begin{array}{l}\text { 18-22 July } \\
2011\end{array}$} & $\begin{array}{l}\text { Semi-structured } \\
\text { interviews (Rapa } \\
\text { Nui) }\end{array}$ & $\begin{array}{l}\text { Trained biologist and Master } \\
\text { in Wildlife Management and } \\
\text { Conservation (RAV, KSG) }\end{array}$ & $\begin{array}{l}\text { Hanga Roa-Hanga Piko, } \\
\text { Rapa Nui, Chile }\end{array}$ \\
\hline & $\begin{array}{l}\text { Digital database } \\
\text { searching }\end{array}$ & $\begin{array}{l}\text { Biologists, Master, PhD } \\
\text { (RAV, KSG, RP, HBG) }\end{array}$ & Online \\
\hline
\end{tabular}

Twenty-seven in-depth and semi-structured interviews were performed in the main Rapa Nui fishing coves: Hanga Roa and Hanga Piko bays. Both locations are in the southwestern portion of the island, where most of the population is concentrated. Interviews were conducted with 19 men and 8 women, who are Indigenous inhabitants of Rapa Nui or people who had lived there for more than ten years, and aged between 18 and 60. Participants were chosen opportunistically and directly approached. All agreed to be part of the study with previous oral consent, guaranteeing voluntary participation and confidentiality regarding personal information. The interviews included open-ended and closed-ended questions and lasted 
approximately 20-30 minutes. Seventy-seven percent $(n=35,100 \%)$ of the potential respondents approached agreed to participate, resulting in a good response rate for the interviews.

We spent one month on Rapa Nui (Table 1) collecting data and interacting with local stakeholders to refine our research. During this period, we took hundreds of pictures, and participant observation was carried out to assess Rapanui culture and its relationship with sea turtles.

\section{Content analysis}

We combined qualitative data and content analysis to identify key themes that regularly emerged from the gathered data (Barrios-Garrido et al, 2017; D'Lima et al, 2014) (Table 2). To understand the Rapanui communities' perceptions of sea turtles, as they are based on people's experiences and may be affected by several drivers, we used a practice and cultural factors analysis, following the thematic analysis proposed by Braun and Clarke (2006). We followed this with other investigations, in which six steps were carried out to create a constructivist approach: i) familiarizing yourself with your data; ii) generating initial codes; iii) searching for themes; iv) reviewing themes; v) defining and naming themes; vi) producing the report.

Furthermore, we qualitatively analyzed myths, rituals, traditions, anecdotal evidence, and oral stories related to sea turtles, registered in key themes, and some responses were classified into more than one theme (D'Lima et al, 2014) (Table 2). Quotes included in this article are part of the general feelings of the interviewees and are used as examples of the values of the community toward sea turtles, following the protocol proposed by D'Lima et al (2014). The analysis, interpretation, and understanding of the findings of this research are based using evidence from all data gathered.

\section{Results}

Sea turtles in the beginning of Rapanui culture

Literature reveals sea turtles were present in Rapanui culture since the first inhabitants' arrival (sometime between the $8^{\text {th }}$ and $12^{\text {th }}$ century AD). Turtle bones have been found together with the oldest human remains in a sacred area of the island, suggesting a strong human-turtle relationship since remote times (Hunt \& Lipo, 2006). These animals are well represented in petroglyphs and rock carvings in the island's spiritual centres and locations in the domain of the high-ranking tribe (Figure 2; Luna, 2013; Metraux, 1971; Rolett, 1986). According to St. Johnston these petroglyphs demonstrate a connection between turtles and the 'Sky people', who created Rapa Nui (Lee \& Ika, 1999; Rjabchikov, 2018). Turtles are also present in the Rongorongo tablet (Rapanui writing system based on glyphs and carved into pieces of wood).

Evidence indicates that, in ancient times, Rapanui clan leaders used to wear a woven cloak and belt made of bark and that these items were decorated with Hawksbill turtles' scutes (tortoiseshell or bekko) (Consejo Nacional de la Cultura y las Artes, 2012). Furthermore, these animals were traditionally held in high spiritual regard, being considered sacred beings or even as a guardian God for Rapanui (Abarca, 2013; Luna, 2013). 


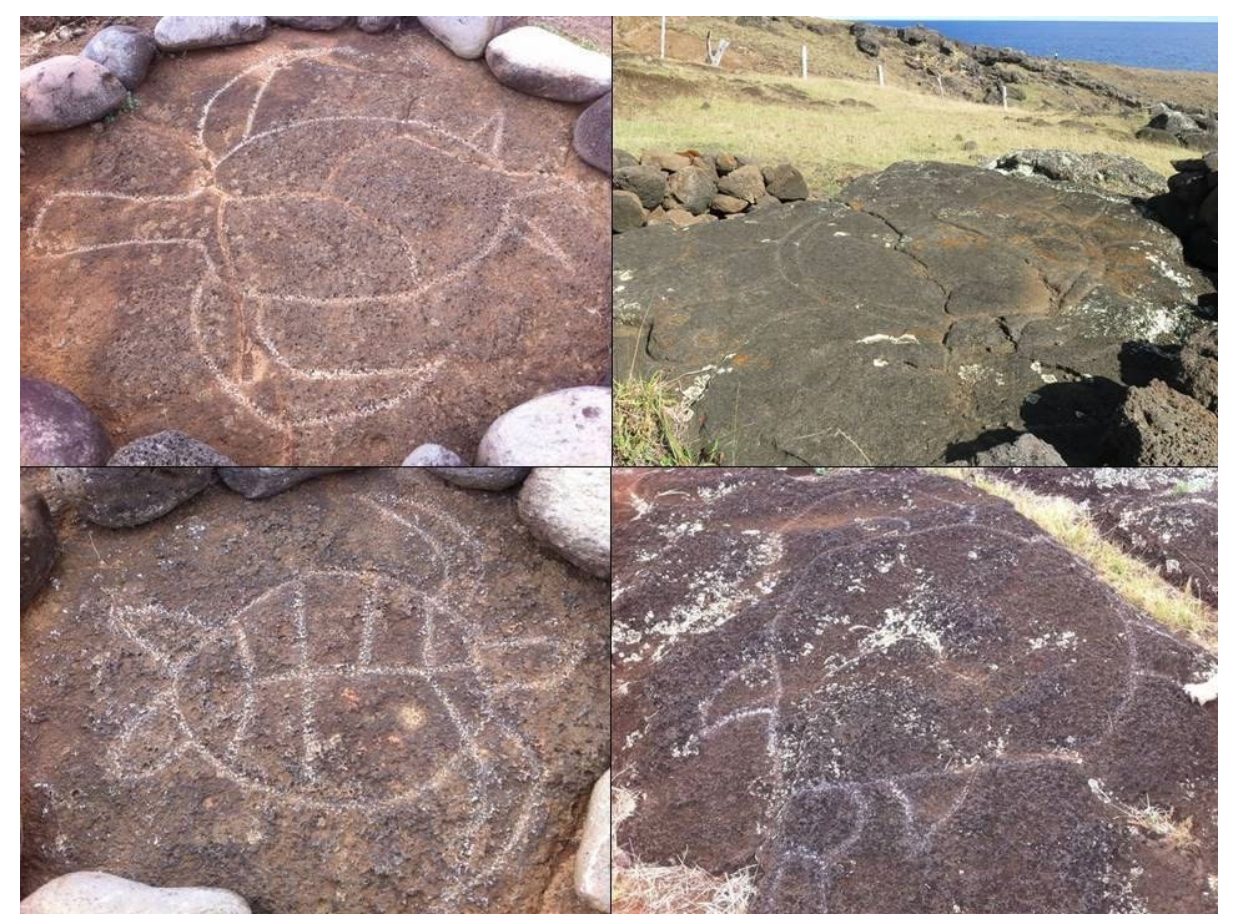

Figure 2. Marine turtle petroglyphs in Rapa Nui. Photos by Carolina Cuevas and Camila González-Johannes.

Presence of turtles in Rapanui legends, mythology, and modern art

Sea turtles are present in foundation myths of the island, as in the following example:

The settlement of Easter Island began with the dream of Haumaka, a man from Hotu Matu'a's kingdom in the land of Hiva. The legend states that seven travellers (then called princes 'arikis') disembarked in Hanga Ho'onu, the indigenous name for 'Turtle Bay' (Bahía de las Tortugas in Spanish) [...] They saw a turtle, which was actually a spirit, and one by one they tried to move it to no avail. The last prince boasted he could do it, lifted it up, and was struck by the turtle's flippers. Mortally wounded, he was taken to a cave and the turtle returned to Hiva. (Museo Chileno de Arte Precolombino, 2012; translation our own)

Mythological stories also refer to sea turtles as guides in the ocean toward Hiva, the land of Hotu Matu'a, and the origin of the Rapanui people:

According to legend in 1600, on the beautiful beach of Anakena, a young and gorgeous lady lived there $[. .$.$] . Her name was Uho [...]. A certain summer afternoon,$ when the young lady was enjoying the delights of bathing, she saw an enormous turtle; she swam with all her strength toward the turtle, when she reached it the turtle said: "I will carry you to the land of Hiva, where you will find your happiness. Hop on my carapace!" (Metraux, 1971; translation our own)

Currently, sea turtles are also part of contemporary art. Numerous Rapanui artists, craftspeople, and sculptors incorporate them into their pieces, demonstrating a strong cultural link between turtles and the arts (Figure 3). 


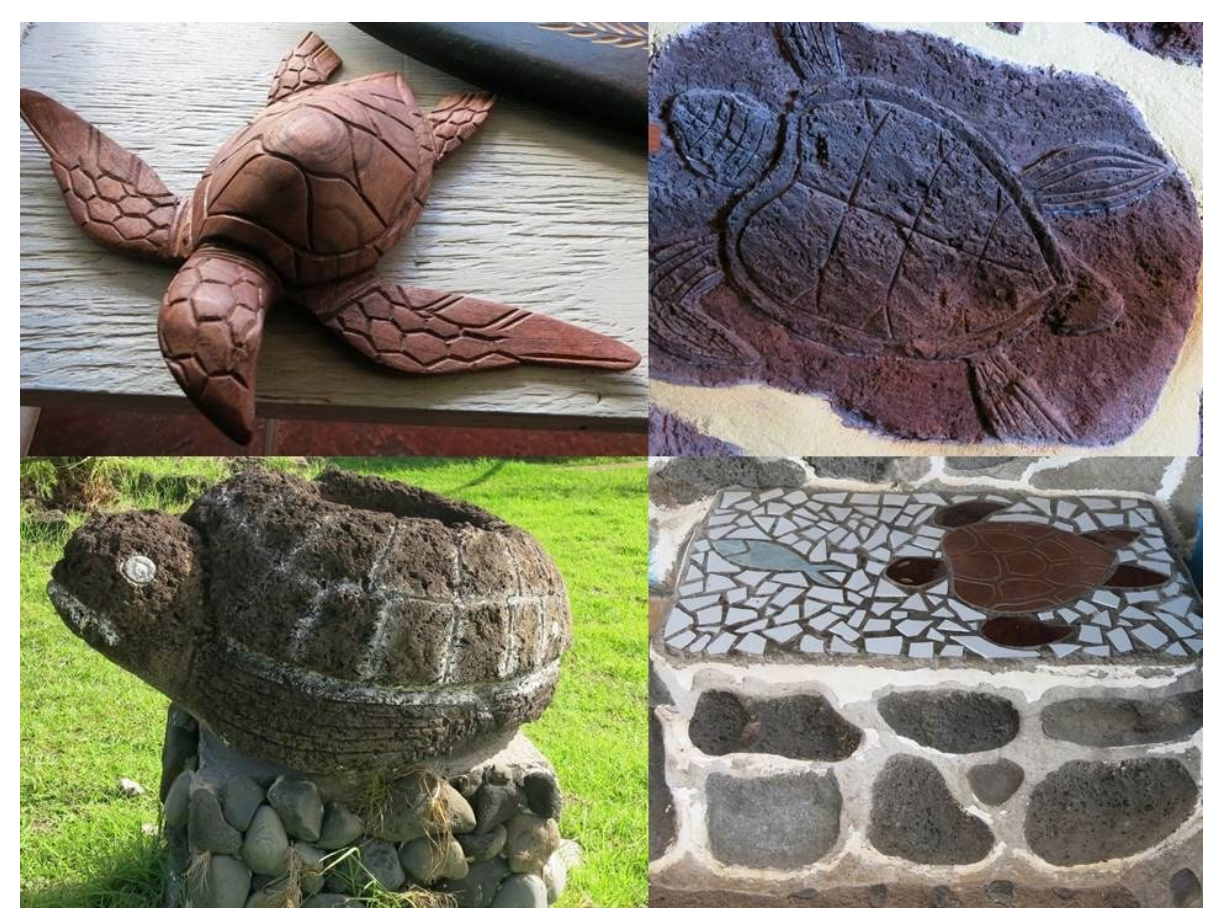

Figure 3. Marine turtle in handcraft and contemporary art of Rapa Nui. Photos by Camila González-Johannes.

\section{Ancient practices of capture and consumption of Rapanui turtles}

Luna (2013), who reviewed literature on turtle use in the Pacific islands, indicated that traditional laws in Rapa Nui restricted their consumption to the king during rituals (Barthel, 1978). Similarly, Metraux (1971) mentioned that turtles on the island were sacred and respected, and their consumption was forbidden for the general community.

Regarding the direct turtle take, Ayres (1979) reported the use of kupenga honu (turtle nets) on the island, and also described the manufacture of diverse types of hooks, which could have been used to capture sea turtles. However, Rapanui stories state that islanders waited for sunset with their harpoons in Hanga Ho'onu (Turtle Bay, nowadays known as Bahía La Perousse), watching for the arrival of turtles from stone towers (Metraux, 1971).

In the past, tapu was enforced by the king of Rapa Nui (Ariki), who ruled the right to use various resources (Aburto et al, 2015; Metraux, 1971; Polet \& Bocherens, 2016). Nowadays, for Rapanui, 'tapu' means restriction or prohibition, as well as respect (Aburto et al, 2015). The main tapu is the closure of the fishing season for tuna and other pelagic fish during the winter months (Aburto et al, 2015). We found no literature that mentioned tapu associated with sea turtle use in Rapanui society.

\section{Local people's perceptions of sea turtles}

In line with the literature, results of our interviews suggest an ancestral connection between Rapanui culture and sea turtles. Rapanui people mentioned that turtles inhabited the island "since the time of Hotu Matu'a" or "since the island's creation," referring to myths, legends, and petroglyphs across the island. We also observed, and the respondents detailed, how nowadays the presence of sea turtles on Rapa Nui has a positive connotation for local residents (Figures $3 \& 4$ ). Values regarding turtles and personal comments from respondents are shown in Table 2. 


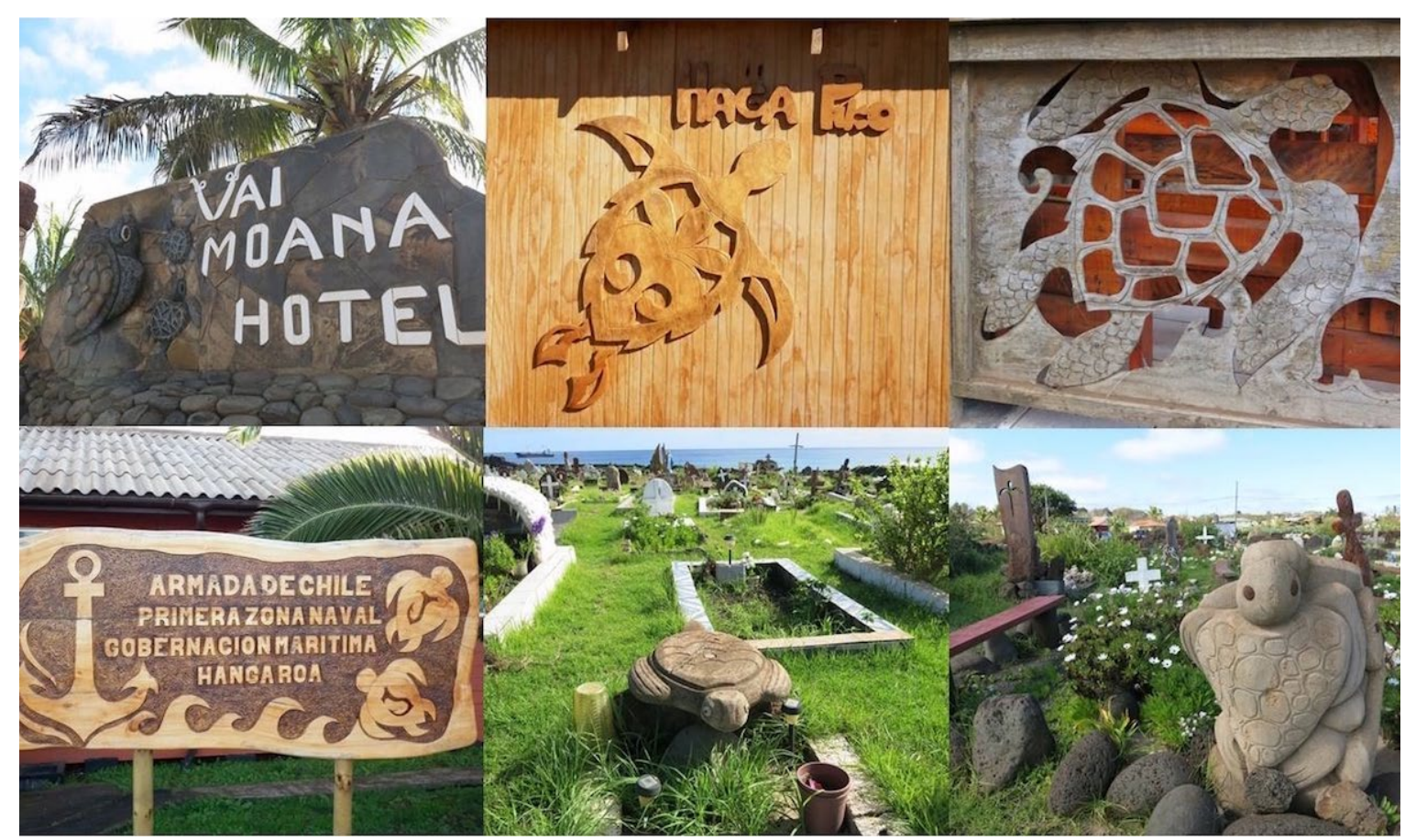

Figure 4. Marine turtle images in façades of commercial structures, Maritime Governorship and the current cemetery. Photos by Camila González-Johannes and Rocío Álvarez-Varas.

Table 2. Themes reflecting perceptions toward sea turtles, values, and illustrated examples.

\begin{tabular}{|c|c|c|}
\hline Theme (No. of respondents) & Value & Illustrated example \\
\hline $\begin{array}{l}\text { Sea turtles as a touristic attraction } \\
(\mathrm{n}=22)\end{array}$ & Cultural & $\begin{array}{l}\text { "when tourists arrive, the first they do is ask } \\
\text { about sea turtles" (R4) }\end{array}$ \\
\hline $\begin{array}{l}\text { Sea turtle as part of the Rapanui } \\
\text { culture }(n=19)\end{array}$ & Cultural & $\begin{array}{l}\text { "sea turtles are very important for the } \\
\text { Rapanui culture" (R12) } \\
\text { "on the island, turtles are one of the things } \\
\text { that are mostly protected" (R3) } \\
\text { "fishermen do not let anybody bother the } \\
\text { turtles, they feed them, and they touch the } \\
\text { turtles when they approach them" (R1) } \\
\text { "kids over here touch them but fishermen } \\
\text { don't let the turtles be disturbed" (R4) }\end{array}$ \\
\hline $\begin{array}{l}\text { Sea turtles as harmless and } \\
\text { charismatic animals }(n=16)\end{array}$ & Utilitarian & $\begin{array}{l}\text { "I wish there were more, as they are } \\
\text { remarkable and harmless" (R18) }\end{array}$ \\
\hline $\begin{array}{l}\text { Sea turtles being used as economic } \\
\text { resource }(n=11)\end{array}$ & $\begin{array}{l}\text { Economic } \\
\text { Economic/ } \\
\text { Utilitarian } \\
\text { Utilitarian }\end{array}$ & $\begin{array}{l}\text { "tourists ask to take pictures with the basking } \\
\text { turtles" (R21) } \\
\text { "fishermen use sea turtles as tourist } \\
\text { attractions" (R15) } \\
\text { "here, we take great care of turtles because } \\
\text { they attract tourists" (R1) } \\
\text { "fishermen hold the turtles so } \\
\text { tourists can take pictures" (R18) }\end{array}$ \\
\hline Sea turtles as food $(n=7)$ & Cultural & $\begin{array}{l}\text { "I know someone that ate a turtle that was } \\
\text { hurt, without a flipper, that's why they } \\
\text { sacrificed it, when it got caught in the net" (R10) }\end{array}$ \\
\hline
\end{tabular}




\begin{tabular}{l|l|l}
\hline & Utilitarian & $\begin{array}{l}\text { "50 years ago, they used to be caught for } \\
\text { consumption, but few, one or two a year" (R16) } \\
\text { "20 years ago, they caught them [turtles] } \\
\text { when they were trapped in the nets, they } \\
\text { were slaughtered and sold to hotels, [for] } \\
\text { turtle soup" (R20) }\end{array}$ \\
\hline $\begin{array}{l}\text { Sea turtles as protectors or good } \\
\text { luck }(\mathrm{n}=5)\end{array}$ & Mythical & $\begin{array}{l}\text { "if we find a turtle in the net, we release it [...] } \\
\text { because if you kill it, you will bring bad luck" } \\
\text { (R18) } \\
\text { "turtles bring good luck when they are seen } \\
\text { in the ocean" (R27) }\end{array}$ \\
\hline $\begin{array}{l}\text { Sea turtles as guides for sailors } \\
(\mathrm{n}=3)\end{array}$ & Mythical & $\begin{array}{l}\text { "they are guides because they always come } \\
\text { ashore" (R25) } \\
\text { "turtles are very important for Rapanui } \\
\text { people, they guide the sailors" (R8) }\end{array}$ \\
\hline
\end{tabular}

Contemporary practices of sea turtle capture and consumption on Rapa Nui

During our interviews, two respondents stated that they had hunted turtles using harpoons. According to them, the hunts were a result of specific circumstances in which food was scarce on the island approximately 30 years ago. Hence, they decided to find alternative means of feeding their families. Despite the low number of interviewees who admitted to practicing the direct capture of turtles on Rapa Nui, 11 of the 27 interviewees claimed to know people who had captured turtles with harpoons at least once. Those turtles were illegally consumed or sold. However, most interviewees in 2011 stated that the consumption of sea turtles had been common practice on the island "three or four decades ago." Nowadays the consumption of sea turtles is widely rejected by the Rapanui community and is considered unjustifiable. Some comments from interviewees regarding this topic were:

Once a young guy came with a turtle that he caught in his net, and we forced him to release it. (Rapanui fisherman; R18)

When I was a kid, I caught one turtle with my net, and I carried it to my house. Then, my grandfather punished me, and made me release it in the ocean. Here, nobody is going to take the risk to be repudiated by community members. (Rapanui businessman; R26).

Seven women and men, between 40 and 60 years of age, said they had eaten turtle meat. Only one said he had eaten turtle meat on another island (Tahiti, where he lived). The respondent said:

"Turtle meat is delicious, we used to eat a lot of turtle meat in Tahiti [...] There it is really common to eat turtle meat, not like here." (Rapanui fisherman; R23)

Another interviewee stated: 
"I do not know why here we have so many turtles, if nobody can eat them." (non-native fisherman; R15)

Although fishing is currently very important on the island, fishermen stated that they seldom interacted with turtles and that they generally released bycatch individuals when they became trapped in fishing nets. Some respondents' comments were:

"Sometimes the turtles are found in the nets, then we need to take them out as soon as possible." (non-native diver and fisherman; R22)

"We don't find turtles in our nets, but if this happens, we release them. We respect the turtles." (Rapanui fisherman; R24)

Occasionally, when dead turtles are found, the respondents reported collecting the shell for ornamental purposes or to sell to tourists. In addition, some fishermen noted that restaurants on the island sometimes asked for turtle meat (for consumption by tourists), for which they offered large sums of money. In general, interviewees claim that they respect these animals (Table 2).

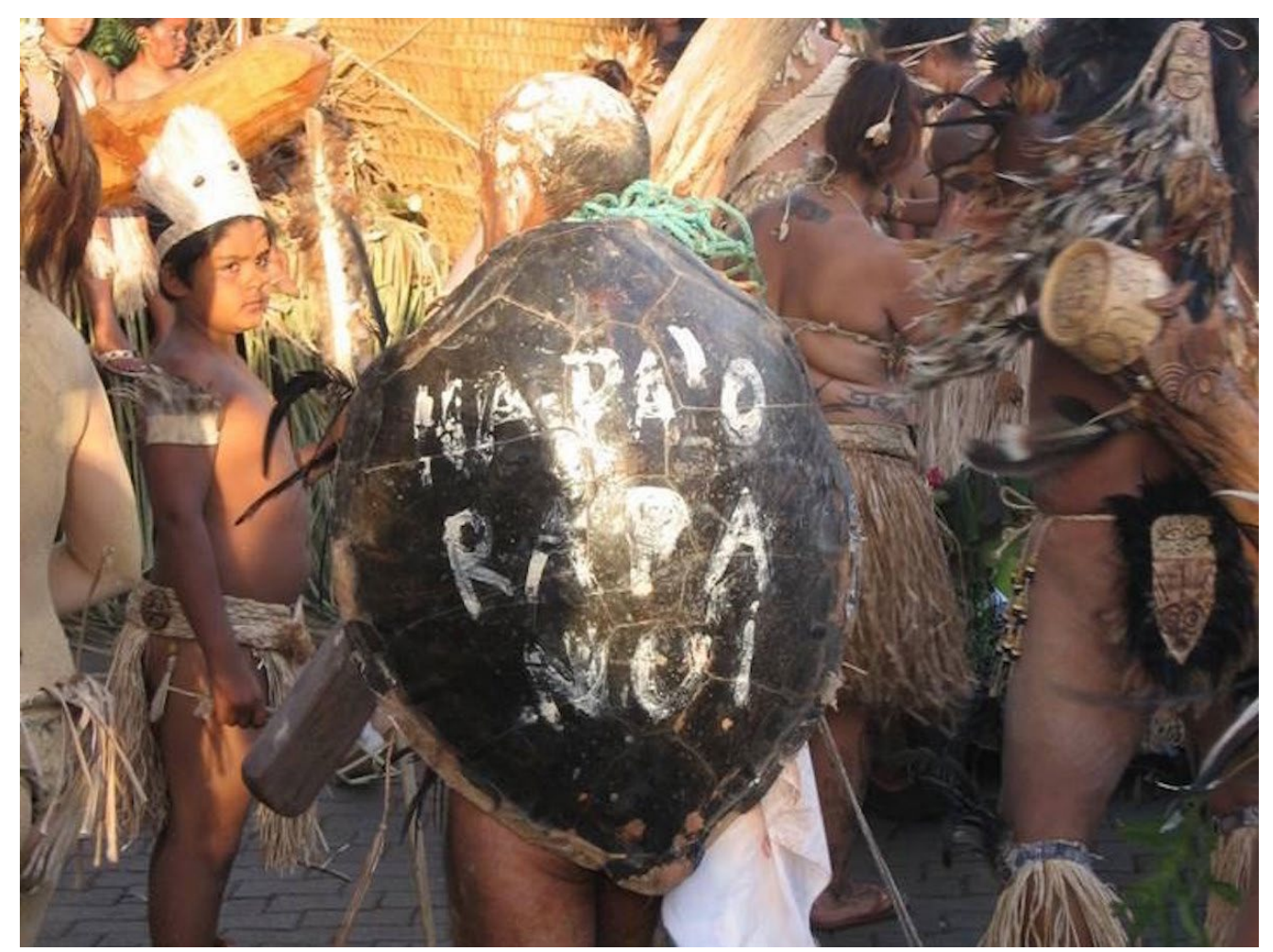

Figure 5. Man using a real turtle carapace on his back in the Tapati festivity. Photo by Camila González-Johannes.

\section{Sea turtles and tourism}

We observed dozens of turtle images, which are also used in tourism activity. According to the interviewees and participant observation, these animals are 'profitable' as images for 
tourism. Many different commercial structures, hotels, shops, restaurants, and even the current cemetery use images of sea turtles on their façades (Figure 4).

Moreover, these animals have been incorporated into the Tapati, a popular celebration of Rapanui culture. Tapati has been celebrated since the mid- $20^{\text {th }}$ century and is one of the most important opportunities for exhibiting this culture to visitors (Consejo Nacional de la Cultura y las Artes, 2012; Ramirez, 2010). During this festival, turtles have been represented by a man who uses a real turtle carapace on his back to promote the cleaning of the island's beaches (Figure 5). Comments from respondents about the role of sea turtles in Rapanui tourism are shown in Table 2.

\section{Discussion}

Spatial variation in sea turtle use throughout the Pacific region

Sea turtles are rooted in traditional societies and are part of Pacific Islanders' cosmology. On Rapa Nui, these animals have been of great cultural and spiritual relevance since ancient times as part of the Rapanui community traditions. This historic value of turtles for the islanders prevails today and was reflected by the interviewees, who recognized the presence of these animals on the island since the times of Hotu Matu'a.

As on other Pacific islands, such as Hawai'i, Samoa, and French Polynesia, sea turtles on Rapa Nui are well represented in petroglyphs and rock carvings at spiritual centres (Figure 2; Luna, 2013; Metraux, 1971; Rolett, 1986). According to Rolett (1986), as in the Society Islands, turtle petroglyphs on Rapa Nui have an archaeological association with significant religious sites. This spiritual relevance is also congruent with that reported for French Polynesia, where these animals are regarded as the link between the living and the dead, the mediator between Heaven and Earth, and a gift from deceased ancestors (Luna, 2013).

Nowadays sea turtles in Rapanui society represent protector beings, guides for sailors, and harmless and charismatic animals (Table 1). These results are similar to the perceptions of other Pacific Islanders on turtles (Luna, 2013).

Woven cloaks and belts decorated with Hawksbill's scutes used by Rapanui clan leaders are comparable with turtle shell plaques used in festival headdresses, which were considered family heirlooms and worn by chiefs, warriors, and male dancers in the Marquesas (Ivory, 2005).

Turtles have also played a key role in the mythology, legends, and art of these societies (Allen, 2007; Balazs, 1983; Kinan \& Danzell, 2005). Many myths and legends exist surrounding sea turtles in this region. Common features of legends include turtles as sons and daughters of gods, humans who can change back again at will, possessors of wisdom and magical powers, and as great warriors and ancestors of royal blood lines (Luna, 2013). Additionally, various creation narratives are associated with these species (Bataille-Benguigui, 1988; Tatarata \& Fretey, 1995). On Rapa Nui, sea turtles have also been considered sacred beings and part of the creation narratives of the island, associated with Hotu Matu'a and Hiva, the origin of the Rapanui people.

Throughout the Pacific, the collecting or eating of turtles and their eggs was forbidden completely or restricted to particular locations, events, clans, castes, age groups, and genders (Luna, 2003). In general terms, consumption was taboo for women, and turtles were consumed only by high-ranking individuals (Allen, 2007; Luna, 2003, 2013). Traditional accounts show differences in turtle butchering and cooking and even specific names have 
been given to the intestines and fat according to their location in the body (Allen, 2007). Netting and grappling have been the most commonly mentioned capture techniques, both still used today (Allen, 2007; Pritchard, 1995). Spearing and harpooning are also reported, but are generally considered modern techniques (Allen, 2007; Balazs, 1983).

Recently, Polet and Bocherens (2016) studied the ancient Rapanui diet through stable isotopes. Gender differences were found, indicating that men had a higher animal protein intake than women. The highest stable isotope values were detected in the Royal Ahu, located in Anakena, suggesting a higher consumption of marine products at that Ahu, and it is likely associated with a tapu imposed on the rest of the community. Although the Polet and Bocherens (2016) study found no turtle remains, Hunt and Lipo (2006) performed an archaeological excavation in Anakena and recovered identifiable turtle bones in the area. These results, together with historical accounts, suggest that turtle consumption on Rapa Nui could have been associated with the king and the elite, being tapu for women. Also, it is probable that Rapanui people used harpoons and nets (kupenga honu) to catch turtles exclusively for the elite and Ariki's consumption.

Although we do not have evidence of tapu associated with turtle use, the described pattern is adjusted to a strictly enforced and formalized control over turtle use in Rapanui culture (Allen, 2007), which likely provided a buffer on the number of turtles harvested, thus maintaining healthy populations.

People inhabiting the United States Pacific territories (Hawai'i, Guam, American Samoa, and the Commonwealth of the Northern Mariana Islands) lost their cultural rights to harvest turtles when the US Endangered Species Act rendered harvest illegal (Kinan \& Danzell, 2005). Since then, they demand an allowable cultural harvest of turtles to perpetuate and strengthen their cultural identity. In contrast to these realities, our 2011 interviews showed that the consumption of turtles on Rapa Nui was habitual "three or four decades ago," probably when food was scarce for most people on the island and their access was restricted by the Chilean Navy (Consejo Nacional de la Cultura y las Artes, 2012). Indeed, today, turtle consumption is widely rejected by the local community.

Interviewees indicated that turtles currently represent beneficial animals mainly for tourism (Table 1). This current importance of turtles in tourist activities was also demonstrated by the presence of turtle images on various commercial structures, hotels, shops, and restaurants across the island (Figure 4). Such results are concordant with Luna (2013), who reported a remarkable use of turtle images as icons and symbols in tattoos, homes, vehicles and businesses in Hawai' $i$, and suggested that visitors and residents place an extremely high cultural value on sea turtles in the Hawai'ian archipelago.

\section{Temporal variation of sea turtles' cultural role on Rapa Nui}

Overall, our study shows a temporal change in the role and use of sea turtles on Rapa Nui, by passing from a highly restricted use by the king in ancient times to a consumption related with certain socioeconomic circumstances (i.e., food shortage), to today's total disavowal of the consumption of a 'resource' associated with tourism value.

Numerous historical events, from the societal and ecological collapse to colonialism and growing tourism, resulted in a change of the ancient sociopolitical structure and in the loss of 
traditional knowledge on Rapa Nui (Aburto et al, 2015; Mulrooney, Ladefoged, Stevenson, \& Haoa, 2009; Young, 2012), as occurred on many other Pacific islands (Johannes, 1978).

The occupation by foreigners resulted in the inclusion of new laws, customs, and markets and contributed to further changes in the use of and control over the natural resources (Johannes, 1978; Ramirez, 2010). Moreover, the introduction of commercial fishing and new fishing gear brought new management challenges to traditional societies (Johannes, 1978; Luna, 2013). These changes on Rapa Nui have probably led to modifications in the islanders' diets by introducing new consumption practices and different products to utilize (Ramirez, 2010). Likewise, high tourism demand has led to traditional laws or tapu associated with the use of certain natural resources to no longer be respected by the local community (Aburto et al, 2015). Consequently, tourism seems to be a main driver of change in terms of the sea turtle's role on Rapa Nui, and probably the use of other natural resources. This is similar to the findings registered by Gowreesunkar, Naqvi, \& Séraphin (2018) in Ilot Bernaches, at Mauritius Island.

Ecotourism has been proposed as an alternative use of sea turtles, one that could bring economic benefits to local communities and encourage their participation in conservation (Campbell, 2007; Gowreesunkar et al, 2018). Turtle-based tourism generates indirect benefits by providing lodging, food, guiding, and other services. Indeed, some sites are extremely dependent on turtle-based tourism. For instance, in Hawai' $i$, as ecotourism increased, turtle watching became an increasingly popular activity, with turtles being one of the most important marine life attractions in the archipelago today (Luna, 2013).

Since the end of the $19^{\text {th }}$ century, Rapanui people have been strongly subjugated by those who administered the island (Yáñez, 2004; Young, 2012). A national debate on the demands of the Rapanui people for self-determination began in the early 2000s. The authorities and Rapanui representatives have leaned toward seeking an autonomous status that would allow them to exercise control over the island and establish policies in the social, economic, and cultural spheres (Yáñez, 2004; Young, 2012). In the same way, the Rapanui seek the restitution of collective ownership over the land and autonomy over the use of natural resources by the original inhabitants (Consejo Nacional de la Cultura y las Artes, 2012; Young, 2012). In this sense, turtle-based tourism on Rapa Nui may not only represent an alternative economic livelihood and an opportunity for further knowledge and conservation of their natural heritage, but be one of the useful ways to achieve the desired autonomy that the Rapanui people claim.

\section{Conclusion}

Through a cross-cultural ethnographic approach, our study demonstrates a strong cultural connection between Rapanui and sea turtles, similar to that of the rest of the Pacific Region. Our results indicate that although the ancestral significance of sea turtles has been maintained over time, the animals' utilitarian value has changed according to the socioeconomic history of the island. Today, in contrast with other Pacific societies, sea turtle consumption is widely rejected by the Rapanui community, and now plays a major role in tourism, the main source of income for the island. By increasing economic income for the local community and reinforcing the cultural identity, responsible turtle-based tourism may represent an alternative of economic sustenance and social autonomy, as well as an opportunity for further knowledge and protection of their unique natural heritage. 


\section{Acknowledgements}

CONICYT Beca Magíster Nacional, CONICYT Beca Doctorado Nacional No21160168, MSc. Natural Resources Program of the Pontificia Universidad Católica de Chile, CONICYT/FONDAP No 15110006, James Cook University (IPR Scholarship). Thanks to Victoria Castro, Rachel Miller and Betsy Pincheira for helpful suggestions and Natalie Montero who kindly revised the English of the manuscript. We are especially grateful to the Rapanui community, who opened their doors and fascinating culture to us.

\section{References}

Abarca, S. (2013). Manos del alma. Arte escultórico Rapanui a través de la obra de Tomás Tuki Tepano. Santiago: LOM Ediciones.

Aburto, J.A., Gaymer, C.F., Haoa, S., \& González, L. (2015). Management of marine resources through a local governance perspective: Re-implementation of traditions for marine resource recovery on Easter Island. Ocean \& Coastal Management, 116, 108-115. https://doi.org/10.1016/j.ocecoaman.2015.07.008

Allen, M.S. (2007). Three millennia of human and sea turtle interactions in Remote-Oceania. Coral Reef, 26, 959-970. https://doi.org/10.1007/s00338-007-0234-x

Álvarez-Varas, R., Petitpas, R., Stowhas, P., \& Fuentes-Hurtado, M. 2015. Conservation research needs of Easter Island (Rapa Nui) marine turtles. Chelonian Conservation and Biology, 14(2), 184-192. https://doi.org/10.2744/ccb-1134.1

Ayres, W. (1979). Easter Island fishing. Asian Perspectives 22, 61-92.

Balazs, G.H. (1983). Sea turtles and their traditional usage in Tokelau. Atoll Research Bulletin, 279, 1-29. https://doi.org/10.5479/si.00775630.279.1

Barthel, T.S. (1978). The eighth land: The Polynesian discovery and settlement of Easter Island. Honolulu: University of Hawai'i Press.

Barrios-Garrido, H., Espinoza-Rodríguez, N., Rojas-Cañizales, D., Palmar, J., Wildermann, N., Montiel-Villalobos, M., \& Hamann, M. (2017). Trade of marine turtles along the Southwestern Coast of the Gulf of Venezuela. Marine Biodiversity Records, 10(1), 1-12. https://doi.org/10.1186/s41200-017-0115-0

Barrios-Garrido, H., Palmar, J., Wildermann, N., Rojas-Cañizales, D., Diedrich, A., \& Hamann, M. (2018). Marine turtle presence in the traditional pharmacopoeia, cosmovision, and beliefs of Wayuú Indigenous people. Chelonian Conservation and Biology, 17(2), 177-186. https://doi.org/10.2744/ccb-1276.1

Bataille-Benguigui, M.C. (1988). The fish of Tonga, prey or social partners. Journal of the Polynesian Society, 97(2), 185-198.

Braun, V., \& Clarke, V. (2006). Using thematic analysis in psychology. Qualitative research in psychology, 3(2), 77-101. https://doi.org/10.1191/1478088706qp063oa

Campbell, L.M. (2007). Local conservation practice and global discourse: a political ecology of sea turtle conservation. Annals of the Association of American Geographers, 97(2), 313334. https://doi.org/10.1111/j.1467-8306.2007.00538.x

Castilla, J.C., Yáñez, E., Silva, C., \& Fernández, M. (2014). A review and analysis of Easter Island's traditional and artisan fisheries. Latin American Journal of Aquatic Research, 42, 690-702. https://doi.org/10.3856/vol42-issue4-fulltext-3 
Cohen, P.J., \& Steenbergen, D.J. (2015). Social dimensions of local fisheries co-management in the Coral Triangle. Environmental Conservation, 42(3), 278-288. https://doi.org/10.1017/s0376892914000423

Consejo Nacional de la Cultura y las Artes. (2012). Estudio diagnóstico del desarrollo cultural del pueblo RAPANUI. September 13rd. Retrieved from http://www.cultura.gob.cl/estudios/observatoriocultural/estudiodiagnósticodeldesarrolloculturaldelpueblorapanui.htm.

Diedrich, A., \& García-Buades, E. (2009). Local perceptions of tourism as indicators of destination decline. Tourism Management, 30, 512-521. https://doi.org/10.1016/j.tourman.2008.10.009

D’Lima, C., Marsh, H., Hamann, M., Sinha, A., \& Arthur, R. (2014). Positive interactions between irrawaddy dolphins and artisanal fishers in the Chilika Lagoon of Eastern India are driven by ecology, socioeconomics, and culture. Ambio, 43(5), 614-624. https://doi.org/10.1007/s13280-013-0440-4

Figueroa, B.E., Rotarou, E.S. (2016). Sustainable development or eco-collapse: Lessons for tourism and development from Easter Island. Sustainability, 8, 1093. https://doi.org/10.3390/su8111093

Fischer, S.R. (2005). Island at the end of the world: The turbulent history of Easter Island. London: Reaktion Books.

Flenley, J.R., \& King S.M. (1984). Late Quaternary pollen records from Easter Island. Nature, 307, 47-50. https://doi.org/10.1038/307047a0

Foale, S., Cohen, P., Januchowski-Hartley, S., Wenger, A., \& Macintyre, M. (2011). Tenure and taboos: Origins and implications for fisheries in the Pacific. Fish and Fisheries 12(4), 357-369. https://doi.org/10.1111/j.1467-2979.2010.00395.x

Fosberg, F.R. (1960). The vegetation of Micronesia. 1, General descriptions, the vegetation of the Marianas Islands, and a detailed consideration of the vegetation of Guam. Bulletin of the AMNH; v. 119, article 1.

Fretey, J., Hoinsoude, G., \& Soumah, M. (2007). Presence of sea turtles in traditional pharmacopoeia and beliefs of West Africa. Marine Turtle Newsletter, 116, 23-25.

Friedlander, A.M., Ballesteros, E., Beets, J., Berkenpas, E., Gaymer, C.F., Gorny, M. \& Sala, E. (2013). Effects of isolation and fishing on the marine ecosystems of Easter Island and Salas y Gómez, Chile. Aquatic Conservation: Marine and Freshwater Ecosystems, 23(4), 515531. https://doi.org/10.1002/aqc.2333

Gowreesunkar, V.G., Naqvi, M.A., \& Séraphin, H. (2018). Implications of tourism development on islets: Ilot Bernaches, Mauritius, as a destination management case study. Island Studies Journal, 13(1), 251-266. https://doi.org/10.24043/isj.26

Hunt, T., \& Lipo, C. (2006). Late colonization of Easter Island. Science, 311, 1603.

Hunt, T.L., \& Lipo, C.P. (2009). Revisiting Rapa Nui (Easter Island) "ecocide" 1. Pacific Science, 63(4), 601-617. https://doi.org/10.2984/049.063.0407

Hunt, T., \& Lipo, C. (2012). Ecological catastrophe and collapse: The myth of "ecocide" on Rapa Nui (Easter Island). PERC Research Paper No. 12/3. https://doi.org/10.2139/ssrn.2042672

INE. (2017). Resultados Censo 2017. Instituto Nacional de Estadísticas de Chile. Retrieved from http://resultados.censo2017.cl/Region?R=R05 
International Work Group for Indigenous Affairs. (2012). Los derechos del pueblo Rapanui en Isla de Pascua: Informe de Misión Internacional de Observadores a Rapa Nui 2011. Informe 15, IWGIA.

Ivory, C.S. (2005). Art and aesthetics in the Marquesas Islands. In E. Kjellgren, (Ed.) Adorning the world: art of the Marquesas Islands (pp. 25-38). New York: New Haven. https://doi.org/10.1093/gao/9781884446054.article.t054544

Johannes, R.E. (1978). Traditional marine conservation methods in Oceania and their demise. Annual Review of Ecology and Systematics, 9, 349-364. https://doi.org/10.1146/annurev.es.09.110178.002025

Kinan, I., \& Danzell, P. (2005). Sea turtles as a flagship species: Different perspectives create conflicts in the Pacific islands. Maritime Studies, 3(2) and 4(1), 195-212.

Lee, G., \& Ika, K. (1999). Petroglyphs and Legends of Rapa Nui. Rapa Nui Journal, 13(3), 114-118. https://doi.org/10.1353/rnj.2016.0038

Luna, R.W. (2003). Traditional food prohibitions (tapu) on marine turtles among Pacific Islanders. SPC Traditional Marine Resource Management and Knowledge Information Bulletin, 15, 31-33.

Luna, R.W. (2013). Turtlephilia in the Pacific: An integrated comparative analysis from the perspectives of biological, cultural, and spiritual ecology in a particular case of biophilia Ph.D. thesis. University of Hawai'i at Manoa, Hawai'i, United States.

McCall, G. (1997). Riro, Rapu and Rapanui: Refoundations in Easter Island colonial history. Rapa Nui Journal, 11, 112-122.

McCoy, M.A. (1997). The traditional and ceremonial use of the green sea turtle (Chelonia mydas) in the Northern Mariana Islands: With recommendations for its use in cultural events and education. Sea Grant College Program, Hawai' $i$, United States.

Metraux, A. (1971). Ethnology of Easter Island. Honolulu: Bernice P. Bishop Museum Bulletin 160.

Mulrooney, M.A., Ladefoged, T.N., Stevenson, C.M., \& Haoa, S. (2009). The myth of AD 1680: New evidence from Hanga Ho'onu, Rapa Nui (Easter Island). Rapa Nui Journal, 23(2), 94-105. https://doi.org/10.1017/s0003598x00065546

Museo Chileno de Arte Precolombino. (2012). 15 July 15. Retrieved from http://chileprecolombino.cl/arte/narraciones-indigenas/rapa-nui/expedicion-de-lossiete-exploradores/

Polet, C., \& Bocherens, H. (2016). New insights into the marine contribution to ancient Easter Islanders' diet. Journal of Archaeological Science: Reports, 6, 709-719. https://doi.org/10.1016/j.jasrep.2015.09.013

Pritchard, P.C.H. (1995). Marine turtles of the South Pacific. In K.A. Bjorndal (Ed.) The biology and conservation of sea turtles (pp. 253-262). Washington, DC: Smithsonian Institution.

Ramirez, M.F. (2010). El cambio dietario en Rapa Nui. Usos, desusos y significados asociados a los alimentos en sus procesos de producción, distribución, preparación y consumo. Undergraduate Thesis. Universidad Academia de Humanismo Cristiano, Santiago, Chile.

Randall, J.E., \& Cea, A. (2011). Shore fishes of Easter Island. Honolulu: University of Hawai‘ $i$ Press. 
Rjabchikov, S. (2018). The Rapanui Petroglyphs Tell of Turtles. Polynesia Newsletter, 12, 3 17.

Rolett, B., \& Diamond, J. (2004). Environmental predictors of pre-European deforestation on Pacific islands. Nature, 431, 443-446. https://doi.org/10.1038/nature02801

Rolett, B. (1986). Turtles, priests, and the afterworld: A study in the iconographic interpretation of Polynesian petroglyphs. In P.V. Kirch (Ed.) Island societies: archaeological approaches to evolution and transformation (pp. 78-87). Cambridge, Massachusetts: Cambridge University Press.

Tatarata, M., \& Fretey, J. (1995). Tortues marines. In: Polynesie Française: Reconcilier tradition et protection [Marine turtles in French Polynesia: reconciling tradition and protection]. Paper presented to International Congress of Chelonian Conservation Gonfalon, France, July.

Wilmé, L., Waeber, P.O., \& Ganzhorn, J.U. (2016). Marine turtles used to assist Austranesian sailors reaching new islands. Comptes Rendus Biologies, 339(2016), 78-82. https://doi.org/10.1016/j.crvi.2015.12.001

Yáñez, N. (2004). El Acuerdo de voluntades estado de Chile-pueblo Rapa nui: bases normativas para fundar la demanda de autonomía Rapa Nui. In J. Aylwin (Ed.) Derechos humanos y pueblos indigenas: tendencias internacionales y contexto chileno (pp. 419-428). Temuco: Imprenta Austral. https://doi.org/10.1353/rnj.2015.0016

Young, F. W. (2012). 'I Hē Koe? Placing Rapa Nui. The Contemporary Pacific, 1-30. https://doi.org/10.1353/cp.2012.0000

Zylich, K., S. Harper, R. Licandeo, R. Vega, D. Zeller, \& Pauly, D. (2014). Fishing in Easter Island, a recent history (1950-2010). Latin American Journal of Aquatic Research, 42, 845856. https://doi.org/10.3856/vol42-issue4-fulltext-11 